\title{
A Comprehensive Approach to Antioxidant Activity in the Seeds of Wild Legume Species of Tribe Fabeae
}

\author{
Elena Pastor-Cavada, ${ }^{1}$ Rocío Juan, ${ }^{2}$ Julio E. Pastor, ${ }^{2}$ Manuel Alaiz, ${ }^{1}$ and Javier Vioque ${ }^{1}$ \\ ${ }^{1}$ Instituto de la Grasa (CSIC), Avenida Padre García Tejero 4, 41012 Sevilla, Spain \\ ${ }^{2}$ Departamento de Biología Vegetal y Ecología, Universidad de Sevilla, 41012 Sevilla, Spain \\ Correspondence should be addressed to Elena Pastor-Cavada; epastor@cica.es
}

Received 22 October 2015; Accepted 15 February 2016

Academic Editor: Bernd Schneider

Copyright (c) 2016 Elena Pastor-Cavada et al. This is an open access article distributed under the Creative Commons Attribution License, which permits unrestricted use, distribution, and reproduction in any medium, provided the original work is properly cited.

\begin{abstract}
The benefits of polyphenols have been widely demonstrated in recent decades. In order to find new species with a high biological functionality, the antioxidant activity of the polyphenol extracts from seeds of 50 taxa of tribe Fabeae (Lathyrus, Lens, Pisum, and Vicia) from Spain has been studied. Considering the average concentration obtained from the data in the four genera of the Fabeae tribe, Pisum and Lathyrus show the highest average polyphenol concentration. The highest specific antioxidant activity as well as the antioxidant activity coefficient was observed in Pisum and Vicia. However, with respect to the total antioxidant activity, the highest average value was observed in Lathyrus and Pisum. The results obtained reveal that many of the wild taxa examined could be potential source of antioxidants.
\end{abstract}

\section{Introduction}

The polyphenols, including phenolic acids, flavonoids, lignans, and stilbenes, are an extensive group of secondary metabolites having in common a hydroxy-substituted benzene ring in their structure [1]. The legumes are especially rich in flavonoids [2]. A variety of biological functions have been proposed for polyphenols in plants, such as protection against radiation, oxidative damage, and diseases and participation in signalling pathways [3]. Polyphenols have been associated also with the health-promoting effects of consuming fruits and vegetables, and this positive effect has been related to their antioxidant activity [4]. These health-promoting properties include risk from cancer and cardiovascular and neurodegenerative disease [5-8].

The legumes are used for human food, animal feed, and other commercial applications. They have a great world economic importance and play an important role in food nutrition especially in developing countries and the demand for them is expected to increase in the coming years [9].

The tribe Fabeae in Spain presents the genera Vicia, Lens, Lathyrus, and Pisum [10]. These plants, as other legumes, may grow under drought stress conditions and on poor soils due to their capacity to fix atmospheric nitrogen [11]. The polyphenols content and the antioxidative activity of Vicia faba L. [12, 13], V. sativa L. [14], or 28 wild species of Vicia [15] from Andalusia, Spain, have been studied. In Lens there are some studies on polyphenols composition of $L$. culinaris Medicus $[13,16]$. With respect to Lathyrus, studies on polyphenols, such as L. sativus L. [17, 18], L. maritimus Bigelow [19-21], or 15 wild species also from Andalusia [22] have been made. Although there is not too much information about the polyphenol profile in the tribe Fabeae, Šibul et al. [23] examined herb and root extracts of seven legumes and 33 phenolic compounds were identified and quantified. High levels of genistein and daidzein (isoflavones), quercetin (flavonoids), and quinic acid, vanillic acid, and gallic acid (phenolic acids) were found.

In the last decades a large amount of the world phytodiversity has been lost because local varieties and species have been substituted by commercial ones with a high yield and genetic uniformity. To recover and maintain this biodiversity, a diversification of plant species is necessary, and this can be achieved by increasing our knowledge of local species. The aim of the present research was to study and compare the polyphenol content and the antioxidant activity 
of the collected legume species of tribe Fabeae from Southern Spain. These species show the variability of the tribe in the Mediterranean region, which includes both wild and cultivate taxa.

\section{Materials and Methods}

2.1. General Experimental Procedures. (+)-Catechin, $\beta$ carotene, and linoleic acid are products of Sigma (Madrid, Spain). Tween 20 was purchased from VWR (Barcelona, Spain). They were used for the assays.

2.2. Plant Material. Fully matured seed samples were taken from wild populations located in Andalusia (Southern Spain). The seeds were collected from different fruits and specimens in a given population and stored at $-20^{\circ} \mathrm{C}$. Voucher specimens were deposited in the Herbarium of the University of Sevilla (SEV).

2.3. Phenolics Extraction and Quantification. Seeds were ground using a domestic blender and extracted (60 mg) with methanol $(1 \mathrm{~mL})$ by vortexing in Eppendorf tubes at maximum speed for $1 \mathrm{~h}$ at room temperature in the dark. The methanolic extracts were recovered by centrifugation at $11600 \mathrm{~g}$ for $15 \mathrm{~min}$ and stored in the dark at $-20^{\circ} \mathrm{C}$. The total phenolic content of methanolic extracts was determined according to Mazza et al. method [24]. The sample $(10 \mu \mathrm{L})$ was mixed with a solution of $2 \%$ HCL in $75 \%$ ethanol $(240 \mu \mathrm{L})$ in a 96-well microtiter plate. After $10 \mathrm{~min}$, the absorbance of the solution was monitored at $280 \mathrm{~nm}$ to measure total phenolics. Catechin dissolved in methanol was used as a standard. Phenolic content was expressed as milligrams equivalent to catechin per gram of sample.

2.4. Antioxidant Activity. Antioxidant activity was estimated by determination of the peroxidative decomposition of $\beta$ carotene (bleaching) in the presence of linoleic acid and the samples as described by Marco modified method [25]. This method was successfully used by the authors before, where the complete protocol can be found $[15,22,26]$.

2.5. Statistical Analysis. Results are expressed as the mean values \pm standard deviation of several samples except for species with only one population. The data were statistically analyzed by one-way analysis of variance (ANOVA). Means were compared by Scheffe's test. The $K$-means algorithm has been used to group the taxa studied [27]. Lastly, a discriminating analysis has been performed in order to verify whether the parameters used to sever the taxa are actually effective.

\section{Results and Discussion}

The genera Pisum and Lens have shown the polyphenol contents similar to those observed in Lathyrus and Vicia genera $[15,22]$, respectively, (Table 1).

As in the case of Lathyrus and Vicia genera $[15,22]$, the antioxidant activity of the polyphenol extracts in Lens and Pisum seeds has been studied using two experiments. In the first experiment, a quantity of polyphenol equivalent to $2 \mu \mathrm{g}$ of catechin has been extracted, whereas, in the second experiment, the antioxidant activity of the polyphenols extracted was compared to a fixed quantity of flour $(5 \mu \mathrm{L}$ of polyphenol extract).

Considering the average concentration obtained from the data in the four genera of the Fabeae tribe [15, 22], Pisum and Lathyrus are the genera which show the highest average polyphenol concentration; the latter genus $(P<0.05)$ is clearly distinguished from Lens and Vicia genera (Table 1).

Nevertheless, as stated above, a high polyphenol concentration does not mean that the specific antioxidant activity is also high, although it can help to obtain an adequate total antioxidant activity from the species itself.

As revealed in Table 1, the highest average value is observed in the specific antioxidant activity in Pisum and Vicia, even though only Vicia and Lathyrus $(P<0.01)$ are distinguished, as with the antioxidant activity coefficient $(P<0.05)$. However, the value of the antioxidant activity and degradation rate are similar in the four genera studied, although the range of the degradation rate has been significantly higher $(P<0.01)$ in Lathyrus as compared to Vicia (Table 1).

With respect to the total antioxidant activity, Lathyrus genus stands out with a significantly higher average value $(P<0.05)$ than Vicia (Table 2$)$. The highest antioxidant activity coefficient was observed in Pisum and Lathyrus, even though only Lathyrus and Vicia $(P<0.001)$ are distinguished (Table 2). On the other hand, Lathyrus and Pisum are the genera with the lowest range of degradation rate and antioxidant value, although the latter genus does not reveal a significant difference.

In Lathyrus, how its high content of phenols compensates its low average specific antioxidant activity can be observed, making the total antioxidant activity higher than Lens or Vicia which showed polyphenols with a higher specific antioxidant activity (Tables 1 and 2).

In spite of the results obtained at a genus level, the heterogeneity observed, especially in Lathyrus and Vicia, requires the 50 taxa of the Fabeae tribe to be analyzed jointly, regardless of the genus. Thus, considering both polyphenol content and all the results obtained from specific and total antioxidant activity, taxa have been grouped using all parameters simultaneously. Therefore, $K$-means algorithm severs the taxa into four clearly distinguished groups (Table 3).

In order to verify that the parameters used to sever taxa are effective, a discriminating analysis has been performed which uses, apart from the polyphenol content, all the values obtained from both specific antioxidant activity (Experiment 1) and total antioxidant activity (Experiment 2). Table 4 shows an overview of this analysis in which the three discriminating functions are statistically relevant $(P<0.001)$. The groups are fairly well distinguished. Only L. hirsutus L. (Group 1) and L. amphicarpos L. (Group 2) share an intermediate position between both groups (Figure 1).

Table 5 shows that the taxa included in Group 1 have a significantly higher phenol concentration $(P<0.05)$. When comparing these results to the polyphenol contents in 
TABLE 1: Phenolic contents ( $\mathrm{mg} / \mathrm{g}$ seed flour) and antioxidant activity of methanolic extracts ( $2 \mu \mathrm{g}$ catechin equivalents) from studied genera. Results are the average \pm standard deviation of different populations. Superscript letters indicate significant differences between values in the same column (Scheffe's test); ${ }^{*} P<0.05$ and ${ }^{* *} P<0.01$.

\begin{tabular}{lcccccc}
\hline & ${ }^{*}$ Phenolic contents & AOX & DR & ${ }^{* *}$ AA & ${ }^{* *}$ ORR & ${ }^{*}$ AAC \\
\hline Lathyrus & 13.5 & $0.0034 \pm 0.00$ & $0.0087 \pm 0.00$ & $48.23 \pm 9.38^{\mathrm{a}}$ & $0.52 \pm 0.09^{\mathrm{b}}$ & $327.87 \pm 92.16^{\mathrm{a}}$ \\
Lens & 5.5 & $0.0152 \pm 0.01$ & $0.0107 \pm 0.00$ & $54.92 \pm 9.25^{\mathrm{ab}}$ & $0.45 \pm 0.09^{\mathrm{ab}}$ & $379.01 \pm 90.23^{\mathrm{ab}}$ \\
Pisum & 16.7 & 0.0034 & 0.0082 & $65.53^{\mathrm{ab}}$ & $0.35^{\mathrm{ab}}$ & $488.4^{\mathrm{ab}}$ \\
Vicia & 6.0 & $0.0057 \pm 0.01$ & $0.0101 \pm 0.00$ & $57.37 \pm 7.26^{\mathrm{b}}$ & $0.43 \pm 0.07^{\mathrm{a}}$ & $403.81 \pm 75.47^{\mathrm{b}}$ \\
\hline
\end{tabular}

AOX: antioxidant value; DR: degradation rate; AA: antioxidant activity; ORR: oxidation rate ratio; AAC: antioxidant activity coefficient.

TABLE 2: Antioxidant activity of phenols extracted from studied genera per gram of seed flour extracted $(5 \mu \mathrm{L})$. Results are the average \pm standard deviation of different populations. Superscript letters indicate significant differences between values in the same column (Scheffe's test; ${ }^{*} P<0.05$ and $\left.{ }^{* * *} P<0.001\right)$.

\begin{tabular}{lccccc}
\hline & ${ }^{*}$ AOX & DR & ${ }^{*}$ AA & ${ }^{*}$ ORR & ${ }^{* * *}$ AAC \\
\hline Lathyrus & $0.0029 \pm 0.00^{\mathrm{a}}$ & $0.0075 \pm 0.00$ & $57.56 \pm 5.30^{\mathrm{b}}$ & $0.42 \pm 0.05^{\mathrm{a}}$ & $468.64 \pm 62.97^{\mathrm{b}}$ \\
Lens & $0.0044 \pm 0.00^{\mathrm{b}}$ & $0.0117 \pm 0.00$ & $46.99 \pm 19.43^{\mathrm{ab}}$ & $0.53 \pm 0.19^{\mathrm{ab}}$ & $332.59 \pm 165.34^{\mathrm{ab}}$ \\
Pisum & $0.0029^{\mathrm{ab}}$ & 0.0076 & $65.52^{\mathrm{ab}}$ & $0.34^{\mathrm{ab}}$ & $513.87^{\mathrm{ab}}$ \\
Vicia & $0.0045 \pm 0.00^{\mathrm{b}}$ & $0.0191 \pm 0.03$ & $46.66 \pm 10.52^{\mathrm{a}}$ & $0.53 \pm 0.10^{\mathrm{b}}$ & $317.57 \pm 98.85^{\mathrm{a}}$ \\
\hline
\end{tabular}

AOX: antioxidant value; DR: degradation rate; AA: antioxidant activity; ORR: oxidation rate ratio; AAC: antioxidant activity coefficient.

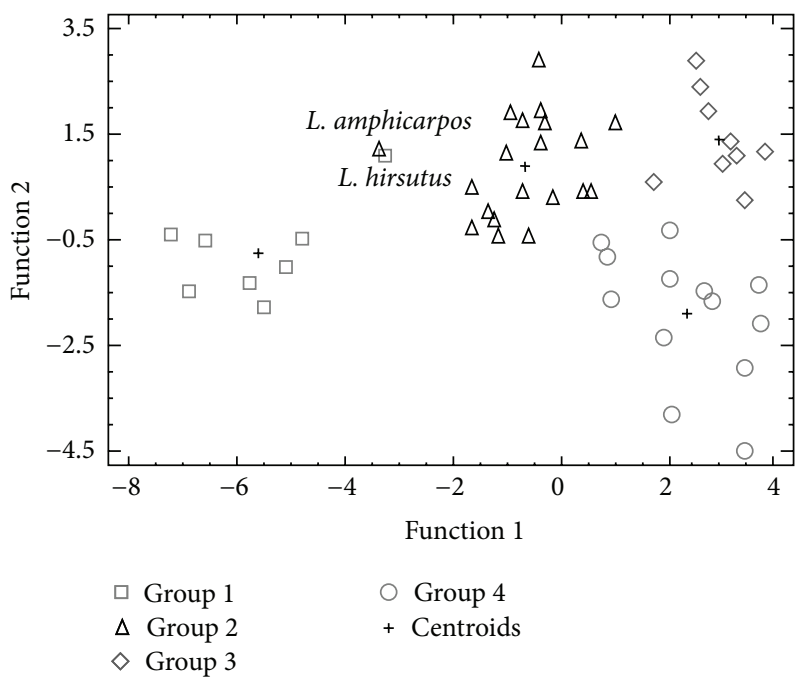

FIGURE 1: Distribution in groups of taxa studied according to discriminant analysis.

the seeds of different cultivated species (lupins, soya beans, and chickpeas), it can be observed that the taxa in Fabeae tribe included in Group 2 reveal a similar concentration to these cultivated species, whereas the taxa in Group 1 have a significantly higher polyphenol quantity (Figure 2).

With respect to the activity of these polyphenols (Tables 5 and 6), most values related to both specific and total antioxidant activity show relevant differences between the groups. Only the specific antioxidant score (AOX) (Table 3) and the total degradation rate (DR) (Table 6) are similar for all four groups of taxa.

Groups 1 and 2 share the same total antioxidant activity coefficient, being the highest score, which makes a clear difference $(P<0.05)$ with Groups 3 and 4 (Table 6).

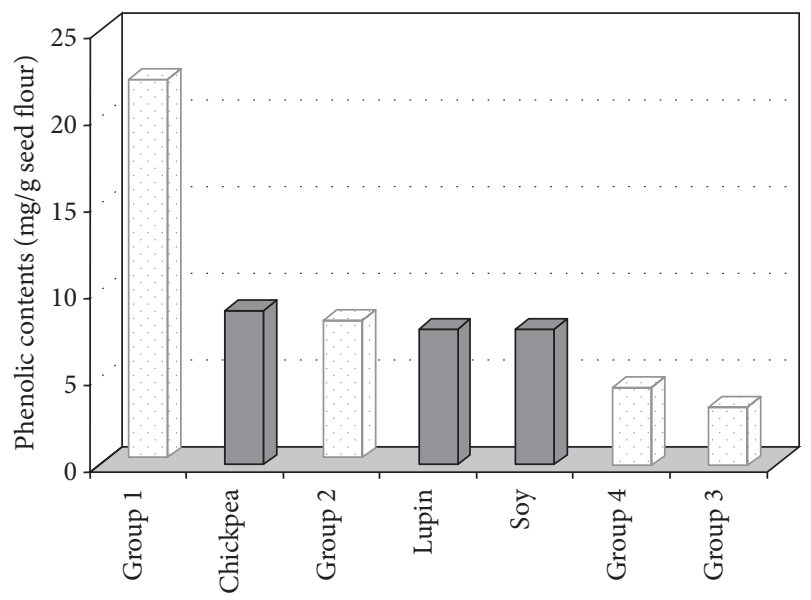

FIGURE 2: Seed phenolic contents for the four groups of taxa belong to tribe Fabeae from Southern Spain and chickpea, lupin, and soy.

Nevertheless, the polyphenol content in both groups is remarkably different $(P<0.05)$, as well as the specific antioxidant activity or specific antioxidant activity coefficient (Table 5). As a result, the total antioxidant activity and the total antioxidant activity coefficient are similar in the two groups (Table 6).

Therefore, when the 50 taxa are analyzed jointly, the negative correlation that was observed between both parameters is maintained, although tightly $\left(R^{2}=34.64\right.$, Figure 3$)$.

\section{Conclusions}

Results obtained reveal that many of the taxa examined could be potential sources of antioxidants, especially the ones belonging to Groups 1 and 2 (Table 3 and Figure 1). Both groups include species that are currently cultivated or have 
TABLE 3: Groups of taxa studied established in relation to their phenolic contents and antioxidant activity (Experiments 1 and 2).

\begin{tabular}{|c|c|c|c|}
\hline & & Taxa & \\
\hline \multirow{3}{*}{ Group 1} & Lathyrus angulatus & L. hirsutus & L. tingitanus \\
\hline & L. aphaca & L. pratensis & Vicia sativa subsp. sativa \\
\hline & L. filiformis & L. sphaericus & \\
\hline \multirow{7}{*}{ Group 2} & Lathyrus amphicarpos & L. setifolius & V. glauca subsp. giennensis \\
\hline & L. annuus & Lens lamottei & V. hirsuta \\
\hline & L. cicera & Lens nigricans & $V$. lutea subsp. cavanillesii \\
\hline & L. clymenum & Pisum sativum subsp. elatius & $V$. onobrychioides \\
\hline & L. latifolius & Vicia angustifolia & $V \cdot$ pubescens \\
\hline & L. ochrus & V. cordata & V.pyrenaica \\
\hline & L. sativus & V. ervilia & \\
\hline \multirow{3}{*}{ Group 3} & Vicia benghalensis & V. incana & V. parviflora \\
\hline & V. dasycarpa & $V$. lathyroides & $V \cdot$ peregrina \\
\hline & $V$. disperma & $V$. monantha subsp. calcarata & V. tenuifolia \\
\hline \multirow{5}{*}{ Group 4} & Lens culinaris & V. hybrida & V. monardi \\
\hline & Vicia altissima & V. lutea subsp. lutea var. hirta & V. narbonensis \\
\hline & V. articulata & V. lutea subsp. lutea var. lutea & $V \cdot$ pseudocracca \\
\hline & V. eriocarpa & $V$. lutea subsp. vestita & V. vicioides \\
\hline & Vicia faba & & \\
\hline
\end{tabular}

TABLE 4: Summary of discriminant analysis based on the phenolic contents and antioxidant activity (Experiments 1 and 2).

\begin{tabular}{lccccc}
\hline Functions & Wilks Lambda & Chi-square & Df & $P$ value & Cumulative percentage \\
\hline 1 & 0.0197511 & 162.8687 & 33 & 0.0000 & 77.22 \\
2 & 0.196516 & 67.5211 & 20 & 0.0000 & 93.30 \\
3 & 0.562703 & 23.8627 & 9 & 0.0045 & 100 \\
\hline
\end{tabular}

TABLE 5: Phenolic contents (mg/g seed flour) and antioxidant activity of methanolic extracts ( $2 \mu \mathrm{g}$ catechin equivalents) for the four groups of taxa belong to tribe Fabeae from Southern Spain. Results are the average \pm standard deviation. Superscript letters indicate significant differences between values in the same row (Scheffe's test; ${ }^{*} P<0.05$ and ${ }^{* * *} P<0.001$ ).

\begin{tabular}{lcccc}
\hline & Group 1 & Group 2 & Group 3 & Group 4 \\
\hline${ }^{*}$ Phenolic contents & $21.8 \pm 6.5^{\mathrm{c}}$ & $7.9 \pm 3.1^{\mathrm{b}}$ & $3.3 \pm 0.8^{\mathrm{a}}$ & $4.6 \pm 2.0^{\mathrm{ab}}$ \\
$\mathrm{AOX}^{\mathrm{a}}$ & $0.0040 \pm 0.00$ & $0.0054 \pm 0.00$ & $0.0082 \pm 0.01$ & $0.0050 \pm 0.00$ \\
${ }^{* * *} \mathrm{DR}^{\mathrm{b}}$ & $0.010 \pm 0.00^{\mathrm{ab}}$ & $0.009 \pm 0.00^{\mathrm{a}}$ & $0.08 \pm 0.00^{\mathrm{a}}$ & $0.011 \pm 0.00^{\mathrm{b}}$ \\
${ }^{*} \mathrm{AA}^{\mathrm{c}}$ & $42.59 \pm 9.17^{\mathrm{a}}$ & $56.56 \pm 5.12^{\mathrm{b}}$ & $65.34 \pm 3.62^{\mathrm{c}}$ & $51.71 \pm 5.65^{\mathrm{b}}$ \\
${ }^{*} \mathrm{ORR}^{\mathrm{d}}$ & $0.574 \pm 0.09^{\mathrm{c}}$ & $0.435 \pm 0.05^{\mathrm{b}}$ & $0.347 \pm 0.04^{\mathrm{a}}$ & $0.482 \pm 0.06^{\mathrm{b}}$ \\
${ }^{*} \mathrm{AAC}^{\mathrm{e}}$ & $267.11 \pm 78.8^{\mathrm{a}}$ & $400.9 \pm 51.9^{\mathrm{b}}$ & $489.50 \pm 41.2^{\mathrm{c}}$ & $346.28 \pm 53.6^{\mathrm{b}}$ \\
\hline
\end{tabular}

AOX: antioxidant value; DR: degradation rate; AA: antioxidant activity; ORR: oxidation rate ratio; AAC: antioxidant activity coefficient.

TABLE 6: Antioxidant activity of phenols extracted for the four groups of taxa belong to tribe Fabeae from Southern Spain per gram of seed flour extracted $(5 \mu \mathrm{L})$. Results are the average \pm standard deviation of different populations. Superscript letters indicate significant differences between values in the same row (Scheffe's test; ${ }^{*} P<0.05$ and ${ }^{* * *} P<0.001$ ).

\begin{tabular}{lcccc}
\hline & Group 1 & Group 2 & Group 3 & Group 4 \\
\hline AOX $^{\mathrm{a}}$ & $0.0028 \pm 0.00^{\mathrm{a}}$ & $0.0034 \pm 0.00^{\mathrm{a}}$ & $0.0045 \pm 0.00^{\mathrm{b}}$ & $0.0053 \pm 0.00^{\mathrm{c}}$ \\
${ }^{* * * *} \mathrm{DR}^{\mathrm{b}}$ & $0.072 \pm 0.00$ & $0.009 \pm 0.00$ & $0.025 \pm 0.04$ & $0.023 \pm 0.03$ \\
${ }^{*} \mathrm{AA}^{\mathrm{c}}$ & $60.06 \pm 8.4^{\mathrm{c}}$ & $56.81 \pm 4.5^{\mathrm{c}}$ & $46.91 \pm 6.3^{\mathrm{b}}$ & $36.73 \pm 7.2^{\mathrm{a}}$ \\
${ }^{*} \mathrm{ORR}^{\mathrm{d}}$ & $0.399 \pm 0.08^{\mathrm{a}}$ & $0.433 \pm 0.05^{\mathrm{a}}$ & $0.532 \pm 0.06^{\mathrm{b}}$ & $0.633 \pm 0.07^{\mathrm{c}}$ \\
${ }^{*} \mathrm{AAC}^{\mathrm{e}}$ & $490.61 \pm 92.2^{\mathrm{c}}$ & $431.59 \pm 55.1^{\mathrm{c}}$ & $315.82 \pm 59.7^{\mathrm{b}}$ & $229.74 \pm 57.3^{\mathrm{a}}$ \\
\hline
\end{tabular}

AOX: antioxidant value; DR: degradation rate; AA: antioxidant activity; ORR: oxidation rate ratio; AAC: antioxidant activity coefficient. 


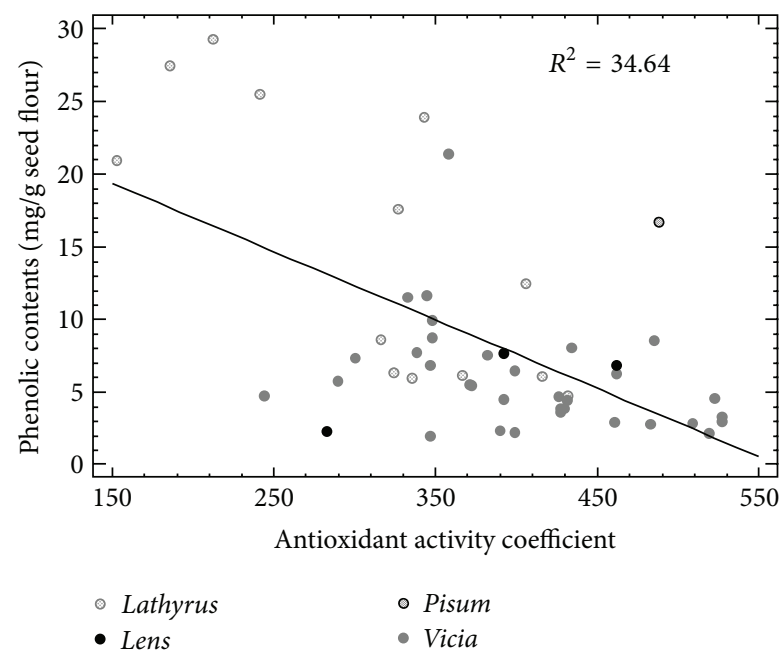

FIGURE 3: Correlation between phenolic contents ( $\mathrm{mg} / \mathrm{g}$ seed flour) and antioxidant activity coefficient in studied genera.

been cultivated in the past, although a great deal of them have never been used in crops and could become alternative sources of antioxidants.

\section{Competing Interests}

The authors have no conflict of interests.

\section{Acknowledgments}

This work was financed by Grant AGR-711 from Junta de Andalucía (Spain).

\section{References}

[1] C. Manach, A. Scalbert, C. Morand, C. Rémésy, and L. Jiménez, "Polyphenols: food sources and bioavailability", The American Journal of Clinical Nutrition, vol. 79, no. 5, pp. 727-747, 2004.

[2] S. Ramos, "Effects of dietary flavonoids on apoptotic pathways related to cancer chemoprevention," Journal of Nutritional Biochemistry, vol. 18, no. 7, pp. 427-442, 2007.

[3] A. J. Parr and G. P. Bolwell, "Phenols in the plant and in man. The potential for possible nutritional enhancement of the diet by modifying the phenols content or profile," Journal of the Science of Food and Agriculture, vol. 80, no. 7, pp. 985-1012, 2000.

[4] N. Balasundram, K. Sundram, and S. Samman, "Phenolic compounds in plants and agri-industrial by-products: antioxidant activity, occurrence, and potential uses," Food Chemistry, vol. 99, no. 1, pp. 191-203, 2006.

[5] R. N. Tharanathan and S. Mahadevamma, "Grain legumesa boon to human nutrition," Trends in Food Science and Technology, vol. 14, no. 12, pp. 507-518, 2003.

[6] C. Ramassamy, "Emerging role of polyphenolic compounds in the treatment of neurodegenerative diseases: a review of their intracellular targets," European Journal of Pharmacology, vol. 545, no. 1, pp. 51-64, 2006.

[7] A.-M. Boudet, "Evolution and current status of research in phenolic compounds," Phytochemistry, vol. 68, no. 22-24, pp. 2722-2735, 2007.
[8] H. E. Seifried, D. E. Anderson, E. I. Fisher, and J. A. Milner, "A review of the interaction among dietary antioxidants and reactive oxygen species," Journal of Nutritional Biochemistry, vol. 18, no. 9, pp. 567-579, 2007.

[9] M. Duranti, "Grain legume proteins and nutraceutical properties," Fitoterapia, vol. 77, no. 2, pp. 67-82, 2006.

[10] S. C. Talavera, S. Aedo, C. Castroviejo et al., Eds., Flora Iberica, vol. 7, CSIC, Madrid, Spain, 1999.

[11] C. G. Campbell, R. B. Mehra, S. K. Agrawal et al., "Current status and future strategy in breeding grasspea (Lathyrus sativus)," Euphytica, vol. 73, no. 1-2, pp. 167-175, 1993.

[12] R. Amarowicz, M. Karamać, H. Kmita-Głazewska, A. Troszyńska, and H. Kozłowska, "Antioxidant activity of phenolic fractions of everlasting pea, faba bean and broad bean," Journal of Food Lipids, vol. 3, no. 3, pp. 199-211, 1996.

[13] R. Amarowicz, A. Troszyńska, N. Baryłko-Pikielna, and F. Shahidi, "Polyphenolics extracts from legume seeds: correlations between total antioxidant activity, total phenolics content, tannins content and astringency," Journal of Food Lipids, vol. 11, no. 4, pp. 278-286, 2004.

[14] R. Amarowicz and R. B. Pegg, "Legumes as a source of natural antioxidants," European Journal of Lipid Science and Technology, vol. 110, no. 10, pp. 865-878, 2008.

[15] E. Pastor-Cavada, R. Juan, J. E. Pastor, M. Alaiz, J. Girón-Calle, and J. Vioque, "Antioxidative activity in the seeds of 28 Vicia species from southern spain," Journal of Food Biochemistry, vol. 35, no. 5, pp. 1373-1380, 2011.

[16] B. J. Xu and S. K. C. Chang, "Comparative studies on phenolic profiles and antioxidant activities of legumes as affected by extraction solvents," Journal of Food Science, vol. 72, no. 2, pp. S159-S166, 2007.

[17] S. S. Deshpande and C. G. Campbell, "Genotype variation in BOAA, condensed tannins, phenolics and enzyme-inhibitors of grass pea (Lathryus sativus)," Canadian Journal of Plant Science, vol. 72, no. 4, pp. 1037-1047, 1992.

[18] X. f. Wang, T. D. Warkentin, C. J. Briggs, B. D. Oomah, C. G. Campbell, and S. Woods, "Total phenolics and condensed tannins in field pea (Pisum sativum L.) and grass pea (Lathyrus sativus L.)," Euphytica, vol. 101, no. 1, pp. 97-102, 1998.

[19] U. D. Chavan, R. Amarowicz, and F. Shahidi, "Antioxidant activity of phenolic fractions of beach pea (Lathyrus maritimus L.)," Journal of Food Lipids, vol. 6, no. 1, pp. 1-11, 1999.

[20] U. D. Chavan, D. B. McKenzie, R. Amarowicz, and F. Shahidi, "Phytochemical components of beach pea (Lathyrus maritimus L.)," Food Chemistry, vol. 81, no. 1, pp. 61-71, 2003.

[21] F. Shahidi, U. D. Chavan, M. Naczk, and R. Amarowicz, "Nutrient distribution and phenolic antioxidants in air-classified fractions of beach pea (Lathyrus maritimus L.)," Journal of Agricultural and Food Chemistry, vol. 49, no. 2, pp. 926-933, 2001.

[22] E. Pastor-Cavada, R. Juan, J. E. Pastor, M. Alaiz, and J. Vioque, "Antioxidant activity of seed polyphenols in fifteen wild Lathyrus species from South Spain," LWT_Food Science and Technology, vol. 42, no. 3, pp. 705-709, 2009.

[23] F. Šibul, D. Orčić, M. Vasić et al., "Phenolic profile, antioxidant and anti-inflammatory potential of herb and root extracts of seven selected legumes," Industrial Crops and Products, vol. 83, pp. 641-653, 2016.

[24] G. Mazza, L. Fukumoto, P. Delaquis, B. Girard, and B. Ewert, "Anthocyanins, phenolics, and color of Cabernet Franc, Merlot, and Pinot Noir wines from British Columbia," Journal of 
Agricultural and Food Chemistry, vol. 47, no. 10, pp. 4009-4017, 1999.

[25] G. J. Marco, "A rapid method for evaluation of antioxidants," Journal of the American Oil Chemists' Society, vol. 45, no. 9, pp. 594-598, 1968.

[26] E. Pastor-Cavada, R. Juan, J. E. Pastor, M. Alaiz, and J. Vioque, "Antioxidant activity in the seeds of four wild Lupinus species from southern Spain," Journal of Food Biochemistry, vol. 34, no. 1, pp. 149-160, 2010.

[27] J. A. Hartigan and M. A. Wong, "Algorithm AS 136: a K-means clustering algorithm," Applied Statistics, vol. 28, no. 1, pp. 100108, 1979. 

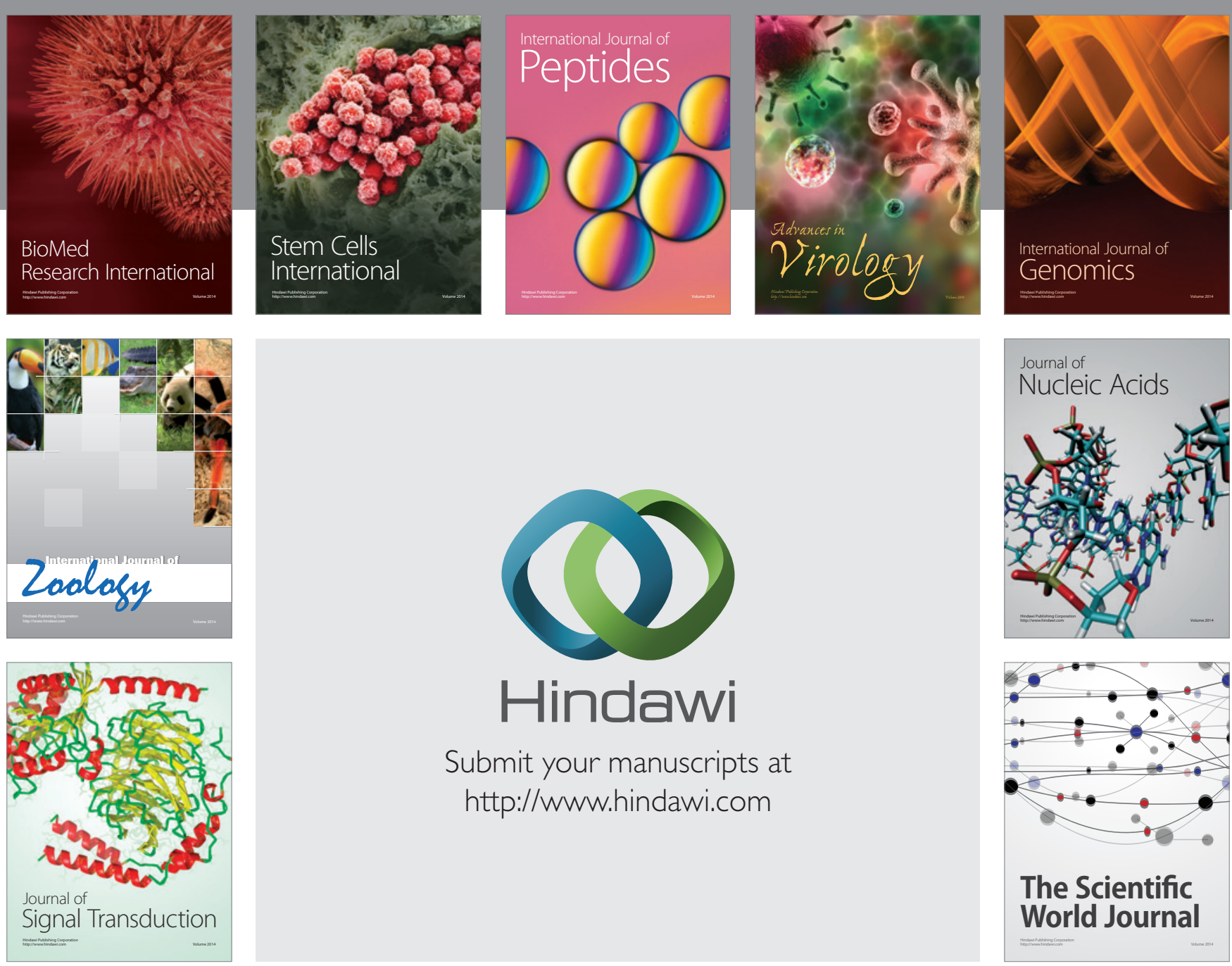

Submit your manuscripts at

http://www.hindawi.com
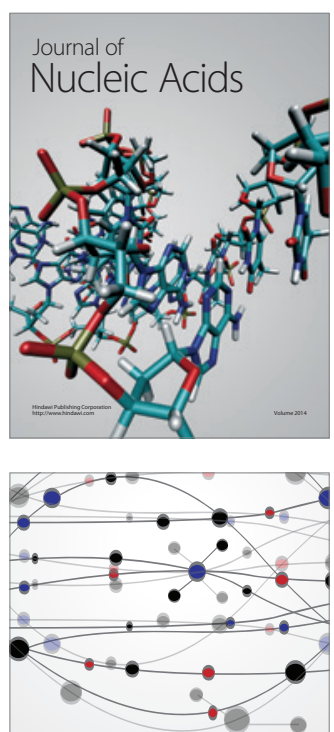

The Scientific World Journal
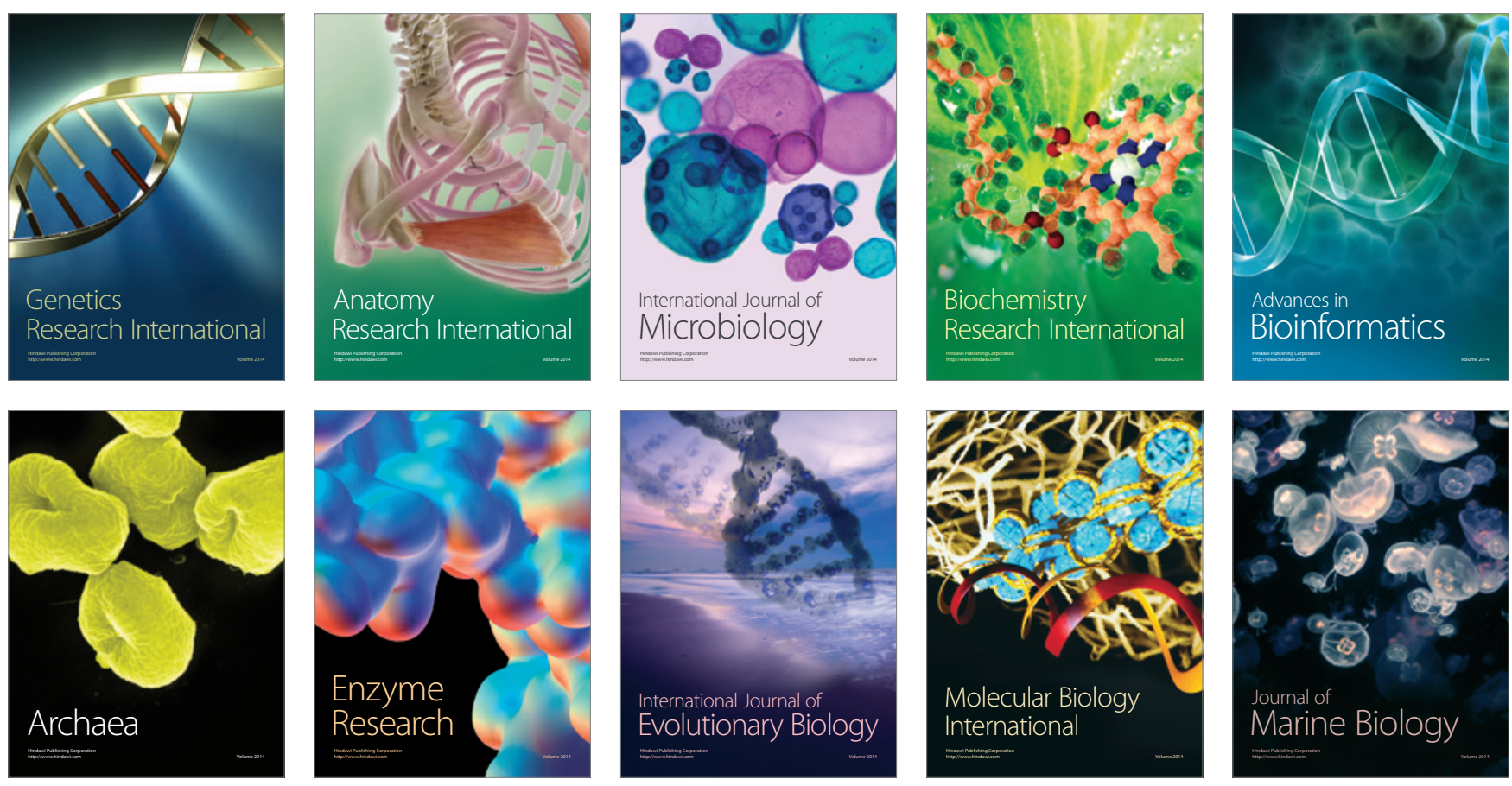